\title{
Jan Grzenia, Komunikacja językowa w Internecie, Wydawnictwo Naukowe PWN, Warszawa 2007, ss. 214
}

Rozważania nad Internetem i innymi sieciami komputerowymi, np.: LAN (Local Area Network) czy WAN (Wide Area Network), mają charakter interdyscyplinarny. O rozwoju tych sieci, różnych aspektach ich funkcjonowania traktują prace licznych badaczy: kulturoznawców, socjologów, psychologów, specjalistów z zakresu komunikacji i mediów. O kwestiach dotyczących sieci komputerowych piszą też filolodzy, zarówno literaturoznawcy, jak i językoznawcy. Publikacja Jana Grzeni wpisuje się również w nurt badań nad Internetem. We Wstępie autor zauważa, że dorobek lingwistów zajmujących się Internetem nie jest bogaty, przeciwnie - przedstawia się dość skromnie. Recenzowana praca w pewien sposób wypełnia lukę: stanowi wprowadzenie do problematyki komunikacji językowej w Internecie. Jest książką znaczącą i potrzebna.

Monografia stanowi zwieńczenie pierwszego etapu badań prowadzonych przez autora nad Internetem. Jej zasadniczy cel to opis zależności łączących lingwistykę i Internet. Grzenia charakteryzuje komunikację internetową nie tyle od strony technicznej czy informatycznej, ile w ujęciu językowym. Analizuje formę i rozwój języka używanego w sieci komputerowej. Rozpatruje kształtowanie się różnych praktyk komunikacyjnych w obrębie tej sieci. Omawia też rozmaite relacje międzyludzkie i wypowiedzi, które funkcjonują za pośrednictwem sieci komputerowych.

W zamyśle badacza jego publikacja winna zainicjować dalsze kompleksowe badania nad językiem w Internecie. W dużym stopniu ma ona charakter porządkujący, tzn. przybliża dotychczasowy stan badań nad wskazaną siecią komputerowa, zawiera liczne pojęciowe i terminologiczne rozstrzygnięcia, typologie, zestawienia cech. Wskazuje też na kolejne perspektywy badawcze. 
Recenzowana praca składa się z trzech rozdziałów: rozdział pierwszy traktuje o komunikacji językowej w ujęciu technologicznym, rozdział drugi poświęcony jest komunikacji elektronicznej, rozdział trzeci dotyczy zagadnień ściśle lingwistycznych - mówi o języku w Internecie.

W rozdziale pierwszym J. Grzenia przedstawia założenia rozwijającej się w krajach anglosaskich dyscypliny, znanej jako computer-mediated-communication. Przywołując licznych specjalistów i ich publikacje, wskazuje na dotychczasowe osiagnięcia w zakresie komunikacji komputerowej. Autor formułuje także postulaty badawcze: „Podstawowym celem tej dyscypliny powinno być badanie komputerów jako narzędzi komunikacji, a przede wszystkim objaśnianie funkcji nowych narzędzi w realizacji jednego $\mathrm{z}$ najbardziej elementarnych procesów zachodzących w życiu ludzi. Równie ważne wydaje się badanie wpływu komputerów na możliwości komunikatywne człowieka, a w konsekwencji także ich wpływu na język" (s. 14). Rozpatrując użyteczność computer-mediated-communication, J. Grzenia określa związek tego terminu z pojęciem „komunikacja elektroniczna”. Odwołując się do ujęcia Bryana Pfaffenbergera, definiuje Internet $\mathrm{i}$ określa jego status $\mathrm{w}$ odniesieniu do innych mediów masowych, tj. prasy, radia czy telewizji. W dalszej części autor wyodrębnia i charakteryzuje internetowe kanały przekazu: gry dyskusyjne, gry internetowe, pocztę elektroniczna, pogawędki internetowe, pracę na komputerach zdalnych, transfer plików, udostępnianie informacji w sieci WWW. Następny podrozdział dostarcza informacji o różnych typach komunikacji w Internecie. Są to: a) typ konwersacyjny, inaczej czatowy, reprezentowany przez rozmaite pogawędki internetowe; b) typ korespondencyjny, inaczej e-mailowy, obejmujący kanały komunikacyjne oparte na liście elektronicznym, a więc: pocztę elektroniczna, grupy, listy i fora dyskusyjne; c) typ hipertekstowy, reprezentowany przez teksty dostępne w sieci World Wide Web (również te, które nie zawierają hiperłączy). Zapowiadając bliższą charakterystykę tekstów w Internecie, J. Grzenia wprowadza kryterium prymarności i sekundarności (wtórności) tekstu, stosowane głównie w opisie przekazów mówionych i pisanych. Na podstawie wskazanego kryterium autor wydziela teksty prymarnie internetowe, tworzone z myślą o Internecie jako medium, w którym będą funkcjonować, oraz teksty sekundarnie internetowe, najpierw rozpowszechniane za pośrednictwem innych mediów, a dopiero potem adaptowane do potrzeb internetowych. Następny z podrozdziałów przynosi opis społeczny użytkowników Internetu w Polsce, przygotowany na podstawie analizy prywatnych witryn internetowych. Według autora opis ten, obejmujący twórców witryn internetowych, winien zapoczątkować dalsze badania, m.in. nad genologią i leksyką internetową. Inne zagadnienie rozpatrywane przez J. Grzenię to czas i miejsce w komunikacji internetowej. Według badacza wskazane parametry zasługu- 
ją na uwage, ,ponieważ kontekst sytuacyjny aktów komunikacji internetowej jest specyficzny, a decydują o nim takie czynniki, jak korzystanie z interfejsu, umowność komunikacji (częściowo zastępująca sytuacyjność tradycyjnej komunikacji mówionej), anonimowość. Również pojęcie i odczucie czasu przewartościowuje się w komunikacji tego typu $-\mathrm{z}$ jednej bowiem strony teksty doraźne (np. pogawędki) zyskują status względnie trwałych, z drugiej teksty przygotowane jako trwałe dość szybko znikają" (s. 50).

W rozdziale drugim J. Grzenia uzasadnia wprowadzenie terminu „komunikacja elektroniczna", najbardziej odpowiedniego dla nazwania procesów porozumiewania się ludzi za pośrednictwem elektronicznych mediów. Zdaniem autora „pozwala on objąć wszelkie media, które mimo znacznego zróżnicowania mają wspólną właściwość: informacje od nadawcy są - za pomocą odpowiedniego urządzenia - przekształcane na sygnały elektryczne lub elektromagnetyczne, a następnie przekazywane w tej formie odbiorcy, który również korzysta z odpowiedniego urządzenia - służącego do rozszyfrowania zapisu i nadania mu zrozumiałej dla człowieka formy" (s. 59). Na bazie tego pojęcia można utworzyć kolejne terminy, przydatne do opisu nowych zjawisk z rozpatrywanego zakresu, m.in.: „tekst elektroniczny”, ,elektroniczny gatunek tekstu” czy „pismo elektroniczne”. Poza tym termin ten nie narzuca sposobu, w jaki muszą być wytworzone i przekazywane teksty (dla porównania „komunikacja medialna” obejmuje wyłącznie przekaz informacji w obrębie mass mediów). Grzenia zauważa również, że ze względu na stosunek łączący nadawcę i odbiorcę wyróżnić można dwa typy komunikacji elektronicznej: asymetryczny i symetryczny. Media asymetryczne, do których należą: prasa, radio i telewizja, to narzędzia przekazu. Role nadawcy i odbiorcy są w nich bowiem z góry ustalone. Interakcja nie jest możliwa lub przebiega z utrudnieniami. Media symetryczne, czyli telefonia i sieci komputerowe, to narzędzia komunikacji. Specyficzna dla nich jest wymiana ról między nadawcą a odbiorcą i wybór odgrywanej roli. W dalszej części J. Grzenia rozważa właściwości komunikacji elektronicznej. Twierdzi, że specyfika opisywanej komunikacji polega m.in. na przekształceniu i przewartościowaniu pojęcia przestrzeni komunikacyjnej. Podkreśla, że komunikacja elektroniczna może mieć charakter synchroniczny (np. pogawędki internetowe) lub asynchroniczny (dobrym przykładem są internetowe witryny, które z uwagi na oparty na hipertekście system World Wide Web moga jednoczyć rozmaite sposoby komunikowania w sieci). Do innych znaczących cech elektronicznej komunikacji badacz zalicza: anonimowość uczestników aktów komunikacji, kreatywny charakter sieci, decentralizację, stanowiącą podstawę internetowego demokratyzmu i egalitaryzmu, oraz autonomiczność, rozumianą jako niezależność Internetu od jakichkolwiek instytucji sprawujących władzę. W omawianym rozdziale 
J. Grzenia rozpatruje też teksty wytworzone za pośrednictwem komputera. Określa je mianem tekstów elektronicznych. Wydziela wśród nich teksty prymarnie pisane i drukowane, które mogą być wtórnie elektroniczne, oraz teksty prymarnie elektroniczne, które mogą być wtórnie drukowane. Koncentrując uwagę na tekstach prymarnie elektronicznych, autor wylicza ich właściwości, np.: plastyczność, sposób utrwalenia, stopień spontaniczności, przeznaczenie. Sygnalizuje współwystępowanie w tego typu przekazach elementów, które są charakterystyczne z jednej strony dla odmiany pisanej, z drugiej zaś - dla odmiany mówionej języka. Rozważania o komunikacji elektronicznej zamyka J. Grzenia uwagami dotyczącymi hipertekstu. Przybliżywszy różne ujęcia hipertekstu, autor proponuje kompilację, która ma ułatwić posługiwanie się tym pojęciem. Rozpatruje funkcjonowanie hipertekstu w opozycji do tekstu tradycyjnego. Wskazuje też na zagadnienia wymagające dalszych, szczegółowych analiz. Są to: dokładny opis relacji między gatunkami pisanymi a ich wariantami hipertekstowymi, ustalenie wpływu hipertekstu na aktualne rozczłonkowanie zdania, opis zmian w konstrukcji i semantyce wypowiedzi, które zachodzą pod wpływem hipertekstu.

Zasadniczą część książki stanowi rozdział trzeci, zatytułowany Język w Internecie. Omawiane zagadnienia dotyczą kształtu języka w sieci, a w szczególności - pisanej realizacji tego języka, słownictwa stosowanego w Internecie, a także genologii internetowej. Na uwagę zasługują również przemyślenia autora na temat wpływu Internetu na zróżnicowanie językowe polszczyzny. Zarysowaną problematykę poprzedza opis sytuacji komunikacyjnych w Internecie, uwzględniający specyfikę kanału przekazu, oficjalność komunikacyjną w sieci, cele uczestników aktów komunikacji oraz tematykę wypowiedzi. Autor omawia też dokładniej wybrane właściwości pragmatyczne, specyficzne dla komunikacji internetowej. Włącza do nich: dialogowość, spontaniczność, kolokwialność, sytuacyjność, multimedialność, hipertekstowość, hierarchiczność, możność zautomatyzowania procesu tworzenia wypowiedzi, dynamiczność, nieograniczony zasięg i trwałość.

Analizując pisownię w Internecie, J. Grzenia wyodrębnia modyfikacje w pisowni (np.: zwielokrotnienie i liter, niestosowanie wielkich liter, sięganie po emotikony i ikony czy pisemne oznaczanie reakcji niewerbalnych) i modyfikacje w interpunkcji (zwielokrotnienie, pomijanie znaków interpunkcyjnych $\mathrm{i}$ ich niestandardowe wykorzystanie). Opis ortograficznych i interpunkcyjnych osobliwości tekstów internetowych dopełniaja pragmatycznojęzykowe komentarze, m.in. tłumaczące zasadność użycia określonego środka.

W obrębie leksyki internetowej J. Grzenia wyróżnia dwie podgrupy. Do pierwszej zalicza leksemy ukształtowane w komunikacji odbywającej się za pośrednictwem Internetu, nazywające zjawiska związane z siecią, a przy tym 
zachowujące tradycyjną formę pisowni. Zdaniem badacza słownictwo informatyczne dzieli się na słownictwo komputerowe (związane tematycznie ze sferą nieinternetową, tzn. ze sprzętem i oprogramowaniem) i słownictwo internetowe (obsługujące komputerową komunikację na odległość). Drugą podgrupę tworzą specyficzne sieciowe formy werbalne i werbalno-graficzne, które mogą przechodzić do innych odmian języka. Są to: adresy elektroniczne, pseudonimy (nicki), emotikony i akronimy. Grzenia uważa, że podane formy odznaczają się cechami, na podstawie których można je uznać za swego rodzaju internetowe leksemy. Twierdzi, że formy te można opisywać, sięgając po metody przyjęte w leksykologii.

Charakterystykę internetowych gatunków tekstu J. Grzenia poprzedza definicją terminu ,gatunek tekstu (wzorzec wypowiedzi)". Wskazuje też na zasadnicze ogniwa proponowanego opisu, tj.: tło komunikacyjne wypowiedzi, kategorie językowe typowe dla danego gatunku mowy/tekstu, właściwości kompozycyjne typowe dla danego gatunku mowy/tekstu. Do internetowych gatunków tekstu - nazwanych tak ze względu na ich niemal wyłączne funkcjonowanie w Internecie - autor zalicza: biuletyn elektroniczny, blog, FAQ (Frequently Asked Questions), poradnik internetowy, formularz elektroniczny, gry tekstowe (MUD, MOO), katalog stron, komentarz, księgę gości, list elektroniczny (e-mail), pogawędkę (chat, czat), stopkę redakcyjną, sygnaturę (wizytówkę elektroniczną) i wątek.

Rozdział trzeci zamykają przemyślenia J. Grzeni dotyczące stosunku polszczyzny stosowanej w Internecie do języka ogólnopolskiego. Badacz zauważa, że język używany w Internecie obsługuje różne i bardzo specyficzne sytuacje komunikacyjne, stąd też zaobserwować można krystalizowanie się internetowych pododmian języka ogólnopolskiego. Te pododmiany to wyspecjalizowane warianty językowe, wykazujące znaczne podobieństwo z gwarami środowiskowymi lub specjalistycznymi. Punkt odniesienia dla dalszych ustaleń stanowi typologia Aleksandra Wilkonia, zgodnie z którą język internetowy jest odmianą pisaną języka ogólnego. Próbując dostosować tę odmianę do schematu A. Wilkonia, J. Grzenia proponuje trzy możliwości. Pierwsza możliwość, mało przekonująca, to uznanie języka internetowego za odmianę funkcjonalną pisaną. Druga - trafna, gdyż dobrze opisuje fakty językowe oparta jest na przekonaniu, że każda z funkcjonalnych odmian ma własną pododmianę (lub wariant) internetową. Trzecia możliwość, jak podkreśla autor, jest dość kontrowersyjna i wymaga czasu, by się utrwalić. Polega na wydzieleniu nowej (obok języka mówionego i języka pisanego) odmiany substancjalnej - języka elektronicznego. Autor przedstawia argumenty uzasadniające takie ujęcie, m.in. istnienie elektronicznej kompetencji komunikacyjnej czy wpływ formy elektronicznej na zmianę zależności między poszczególnymi 
odmianami. W dalszej części rozpatruje zróżnicowanie języka w sieci. Opisuje internetowe odmiany językowe, tj.: język codziennej komunikacji, języki funkcjonalne, socjolekty, profesjolekty.

Monografię zamyka rozbudowana bibliografia obejmująca 265 prac. Sa to nie tylko publikacje językoznawcze (poświęcone m.in. zagadnieniom tekstologicznym czy leksykalnym), lecz także pozycje traktujące o Internecie i innych sieciach komputerowych w szerokiej perspektywie komunikacyjnej i technologicznej.

Książka J. Grzeni jest wartościową publikacją. Autor nie tylko przybliża dotychczasową wiedzę o komunikacji językowej w Internecie, lecz także pokazuje różne aspekty funkcjonowania języka w sieci. Wszelkie spostrzeżenia i uwagi przedstawia w sposób przemyślany, uporządkowany i ciekawy. Liczne ustalenia wzbogaca przykładami i odniesieniami do wcześniej zgromadzonego materiału. Często wprowadza tabelaryczne zestawienia, które dopełniają omówienie i czynią opis bardziej przejrzystym i zrozumiałym. Zastanawiam się jednak, czy monografia nie zyskałaby bardziej na przejrzystości po zmianie przyjętego układu. Chodzi o uwagi dotyczące tekstów internetowych. Są one zamieszczone w poszczególnych paragrafach każdego z rozdziałów. Czy nie lepiej byłoby zaprezentować te uwagi w sąsiedztwie? Może w odrębnym rozdziale traktującym o tekstach (gatunkach) w Internecie?

Recenzowana publikacja zawiera wiele postulatów badawczych, zachęcając w taki sposób do kolejnych poszukiwań i szczegółowych analiz, które jak pisze J. Grzenia - są bardzo pożądane. Rzeczywiście, winny one objąć m.in.: język elektroniczny jako nową substancjalną odmianę, internetowe gatunki tekstu, hipertekst i jego strukturę, słownictwo używane w sieci. Sądze, że należałoby też przyjrzeć się bliżej tekstom w Internecie od strony ich składniowego ukształtowania. Warto byłoby dokładniej scharakteryzować typy wzorców syntaktycznych realizowanych z jednej strony w przekazach oficjalnych, $\mathrm{z}$ drugiej zaś $-\mathrm{w}$ wypowiedziach nieoficjalnych. Równie istotne są rozpoznanie mechanizmów spójności i charakterystyka jej wykładników w poszczególnych gatunkach internetowych.

Niewątpliwym walorem monografii J. Grzeni jest to, że przedstawione w niej wyniki badań mogą być wykorzystane w pracach zarówno językoznawczych, jak i literaturoznawczych. Z pewnością ułatwią filologiczną analizę języka Internetu. 